\title{
Diagnosis of true aneurysms of subclavian and axillary arteries and our principles of surgical approach
}

\author{
O Gokalp, I Yurekli, L Yilik, U Yetkin*, T Gunes, M Akyuz, B Ozcem, O Tetik, G Ilhan, A Gurbuz \\ From 23rd World Congress of the World Society of Cardio-Thoracic Surgeons \\ Split, Croatia. 12-15 September 2013
}

\section{Background}

Although pseudoaneurysms of the subclavian and axillary arteries are relatively common due to trauma and diagnostic/therapeutic interventions, true aneurysms of these arteries are rarely seen.

\section{Methods}

Eight patients that were operated on between February 1998 and December 2007 due to true aneurysms of the subclavian and axillary arteries were examined retrospectively in terms of clinical and perioperative parameters.

\section{Results}

All the patients underwent selective peripheral arteriography, colored Doppler ultrasound and contrasted thoracoabdominal computed tomography $(\mathrm{CT})$. All the patients were operated on under general anesthesia. Subclavicular approach was preferred except for the case operated on for pseudoaneurysm repair. In this particular case, supraclavicular approach was used for the 1st operation and supraclavicular incision plus a partial median sternotomy for the 2nd. Generally, if the calibration of the saphenous vein graft was appropriate for the arterial segment, this venous graft was used. Otherwise, an artificial graft was interposed. If acute ischemia was coexistent, brachial embolectomy was also performed.

\section{Conclusion}

Isolated aneurysm of subclavian or axillary artery is very rarely seen among all peripheral arterial aneurysms. The true aneurysms of these particular arteries are even

\footnotetext{
* Correspondence: ufuk_yetkin@yahoo.fr

Izmir Katip Celebi University Ataturk Training and Research Hospital,

Department of Cardiovascular Surgery, Turkey
}

more seldom. One should be very careful in the diagnosis and treatment processes.

Published: 11 September 2013

doi:10.1186/1749-8090-8-S1-P46

Cite this article as: Gokalp et al:: Diagnosis of true aneurysms of

subclavian and axillary arteries and our principles of surgical approach.

Journal of Cardiothoracic Surgery 2013 8(Suppl 1):P46.
Submit your next manuscript to BioMed Central and take full advantage of:

- Convenient online submission

- Thorough peer review

- No space constraints or color figure charges

- Immediate publication on acceptance

- Inclusion in PubMed, CAS, Scopus and Google Scholar

- Research which is freely available for redistribution

\section{() Biomed Central}

